\title{
Impact of Different Irrigation Methods on Microbial Activity in Chickpea Crop
}

\author{
Neha Singhal*, Poonam Sharma, Mukesh Siag, Rakesh Sharda \\ and Nikhil Gladwin Cutting
}

Punjab Agricultural University, Ludhiana, India

*Corresponding author

\begin{abstract}
A B S T R A C T
Keywords

Chickpea,

Symbiotic traits, Microbial activity, Drip, Flood and Furrow Irrigation

Article Info

Accepted:

15 June 2018

Available Online:

10 July 2018

Field experiment was conducted in winter season of 2016-17 and 2017-18 at PAU, Ludhiana to assess the impact of different irrigation methods on microbial activity and symbiotic traits in chickpea (Cicer arietinum L.) variety PBG-5. Five types of irrigation treatments were applied as drip irrigation in crop grown on plain (T1), drip irrigation in crop grown on ridges (T2), flood irrigation (T3), furrow irrigation(T4) and rainfed (T5). Symbiotic traits as number of nodules per plant and dry weight of nodules were recorded non significant among irrigation treatments ( $\mathrm{T} 1$ to $\mathrm{T} 4$ ) but was significantly more than rainfed treatment (T5) whereas leghaemoglobin content of nodules was found significant among irrigation treatment and recorded more in drip irrigation treatments. Microbial population of bacteria and Rhizobia was found non-significant but population of fungi and p-solubilizer bacteria and dehydrogenase activity was significantly higher in T1, T2 and T4. Significantly higher yields were found in drip irrigation treatments with maximum values under T1 in both years and minimum values were observed under T5. Drip irrigation positively impacts symbiotic traits and microbial activity which leads to better growth and yield.
\end{abstract}

\section{Introduction}

India is one of the largest pulses producing country with 17.56 million tonnes of pulses covering an area of 26.43 million hectares. Chickpea (Cicer arietinum L.) or Bengal gram, a winter-season grain legume, is grown predominantly in arid and semi-arid regions of the Indian subcontinent. In India, total chickpea production was recorded as 7.81 million tonnes in 2016 under an area of 8.39 million hectares yielding about $931.6 \mathrm{~kg} / \mathrm{ha}$
(FAOSTAT, 2018). In Punjab average yield of chickpea was recorded as $1282 \mathrm{~kg}$ per ha in the year 2015-16 which is higher than the national average (Anonymous, 2016).

Water is the most fundamental requirement for cultivation. It is required as such and also carries a great number of supplements for prosperous growth of crop. Since water availability is definite, its judicious use is required to meet the ever increasing irrigation demand. Surface methods of irrigation imply 
the direct application of water to the soil surface and non uniform distribution of water occurs. Furrow irrigation reduces crusting of soil and evaporation losses by allowing more infiltration of water. However, excess water has to be applied to allow lateral movement of water. In conventional flood irrigation practices, the whole field is irrigated and irrigation efficiency is low. Pressurized irrigation systems like drip irrigation of high irrigation efficiency provide effective use of limited water supply, both in terms of volume and rate of flow.

As of late the water system patterns have been changing from surface to drip irrigation in arid and semiarid zones, as it is thought to be a more proficient system and furthermore a cost effective substitute as water and manure utilize efficiencies are enhanced. Use of water and supplements specifically at the crop root level positively influences the yield and water savings (Phene and Howell, 1984). Because of such favourable circumstances, drip system is being broadly utilized in the world. Recent research has shown that in some irrigated situations, grain yield can be improved while reducing the amount of water applied to the crop (Yang et al., 2000, 2001, 2002). Proper irrigation scheduling can be used to optimize crop yield at a given level of crop evapotranspiration, leading to more yield per unit of evapotranspiration.

In case of legume crops, apart from appropriate moisture for plant growth, the soil microbial population, especially rhizobia plays an important role in pulse production. According to (Zahran, 1999) the fact that rhizobia can exist in soils with limiting moisture levels can be emphasized by the presence of rhizobial populations in desert soils and the successful nodulation of legumes. However optimum soil moisture enhances the soil Rhizobia activity. Harpinder Singh (2016) reported a positive correlation between soil microbial population and number of nodules per plant with yield of summer mungbean. He reported higher soil microbial population and number of nodules per plant under drip irrigation as compared to flood irrigation.

It was hypothesised that drip irrigation can be beneficial for increasing microbial activity and nodulation in winter season legume crop of chickpea. It was decided to study the impact of different irrigation methods on the microbial activity and population in the soil. Microbial population is likely to influence nodule formation and yield of the crop. Accordingly the present study was done with the objective of finding the response of microbial activity in the soil to different irrigation methods and subsequent impact on yield of chickpea.

\section{Materials and Methods}

The study was conducted at the research farm of the Department of Soil and Water Engineering, Punjab Agricultural University (PAU), Ludhiana in the winter seasons of 2016-17 and 2017-18. Ludhiana is located at $30^{\circ} 54^{\prime} \mathrm{N}$ latitude and $75^{\circ} 48^{\prime} \mathrm{E}$ longitude at the height of 247 meters above mean sea level. Soil textural classification of the experimental site is sandy loam and the soil is low in nitrogen and organic carbon. The climate of Ludhiana is subtropical semi-arid type with three distinct seasons as summer, monsoon and winter. The temperature ranges from $0^{\circ} \mathrm{C}$ or even less in winter to the maximum temperature as high as $47^{\circ} \mathrm{C}$ in summer. The monsoon season is associated with high humidity and almost $70 \%$ of annual rainfall. In winter season only $10 \%$ of annual rainfall is received.

\section{Irrigation treatments}

There were five treatments - Four irrigation treatments and one treatment was under rainfed condition. Irrigation was applied at 
$100 \%$ ET under all irrigation treatments. Treatments were Drip irrigation in crop grown on level field (T1), Drip irrigation in crop grown on ridges (T2), Flood irrigation (T 3), Furrow irrigation (T4), No irrigation (T5).

Chickpea variety PBG-5 was sown in mid Nov. 2016 and 2017 in randomized block design. Row to row spacing was kept as 30 $\mathrm{cm}$. In case of drip irrigation on plain, one dripline was provided between two rows while in drip on ridges, one dripline on each ridge is provided for two rows of crop grown on each ridge. Number of replications was kept 3 with total number of plots as 15 .

\section{Data collection}

Crop growth parameters as plant height, dry weight of root and shoot, leaf area index, chlorophyll content were recorded at flowering stage. Symbiotic traits like number of nodules per plant, dry weight of nodules per plant and leghaemoglobin content of nodules by the method of Wilson and Reisenauer (1963) were recorded at flowering stage of the crop.

For analysis of soil quality parameters, soil samples were collected from eight distinct places from each replication at $10 \mathrm{~cm}$ depth from different treatments to cover variation within a treatment. One sample was taken in case of flood irrigation and rainfed treatments as condition was similar in whole plot, whereas two samples each were taken from the drip irrigation treatments and furrow irrigation to cover the wet and dry regions in these treatments. For drip irrigation in crop grown on level field samples were collected from between rows with irrigation dripline (RWDL) and between rows without irrigation dripline (RWoDL). In case of drip irrigation in crop grown on ridges and furrow irrigation, samples were collected from ridge and furrow. That is, in all eight samples were analyzed per replication.
Viable microbial count in logarithmic value of colony forming units per gram of soil (log $\mathrm{Cfu} / \mathrm{g}$ soil) was done before sowing, at flowering stage and day after harvesting of crop. The viable population count for bacteria, fungi, rhizobia and p-solubilizer bacteria were determined from soil by pour plate method under different irrigation treatments. The viable count for bacteria, fungi, rhizobia and p-solubilizer (Pseudomonas) was done on Nutrient agar (NA), Potato dextrose agar (PDA), Yeast extract mannitol (YEM) broth and Pseudomonas Agar mediums respectively. After incubation, colonies developed and the viable count of soil microbes were enumerated by following formula.

Colony forming unit $(\mathrm{Cfu})$ per $\mathrm{ml}$ of sample $=$ Number of colonies $x$ Dilution factor

Quantity of sample

Colony forming unit (Cfu) per gm sample was converted in log value using following formula.

$\log \left(a^{X} b^{n}\right)=\log a+n \log b$

Where,

$\mathrm{a}=$ Mean number of bacterial colonies

$\mathrm{b}^{\mathrm{n}}=$ Dilution factor

Dehydrogenase activity of soil was examined as per method of Tabatabai (1982) at flowering stage of the crop.

Yield analysis was done for all the treatments at the time of harvesting for chickpea crop in both years. Various parameters as number of pods per plant, number of seeds per pod, weight of 100 grains $(\mathrm{g})$, grain yield (kg/ha) were recorded. The data collected from the present field experiment was subjected to the statistical analysis using CPCS 1 software using analysis of variance (ANOVA) techniques at 5 per cent level of significance. 


\section{Results and Discussion}

\section{Plant growth parameters}

Different plant growth parameters of chickpea crop at flowering stage are presented in Table1. Plant height varies significantly with irrigation treatment.

Maximum plant height was recorded under drip irrigation treatments which was significantly more than those under furrow irrigation. Minimum plant height was observed under rainfed conditions which significantly lower than all irrigation treatments. Plant height in second year was almost $15-25 \%$ more than first year, which may be due to better weather conditions in second year. There was no significant difference in number of branches for different treatments.

In case of dry weight of roots, there was no significant difference between treatments for chickpea crop in both the years. Dry weight of shoot was significantly less in rainfed condition than the irrigation treatments (T1to T4) in both the years.

Leaf area index under drip irrigation treatment was significantly higher than under flood and furrow irrigation and leaf area index was the least under rainfed conditions which was significantly less than all irrigation treatments.

Better plant height and leaf area index under drip irrigation treatment may be attributed to better soil moisture regime due to frequent irrigation.

Chlorophyll content was observed non significant among different treatments except in chickpea crop in 2016-17 season, where chlorophyll content under rainfed treatment was significantly lower than some irrigation treatments.

\section{Symbiotic traits}

Various symbiotic traits of the crop flowering stage are presented in Table 2 for both years. No significant difference in number of nodules per plant between the irrigation treatments was recorded but was found significantly higher than in case of rainfed plots in the year 201617. Weight of nodules of chickpea crop indicates no significant difference in dry weight of nodules per plant between the irrigation treatments but was significantly higher than in rainfed plots. However, dry weights of nodules were generally maximum under drip irrigation even though number of nodules was more or less equal to flood and furrow irrigation. This may be due to the fact that it was observed that there were more even size nodules under drip irrigation system whereas in flood and furrow irrigation treatment many nodules were of minute size.

Significantly higher leghaemoglobin content under drip irrigation treatments was observed as compared to flood and furrow irrigation treatments and minimum values were recorded under rainfed condition. Since leghaemoglobin content is an indication of the health and relative ability of nodules in nitrogen fixation, hence it may be said that drip irrigation provided more conducive condition for health and activity of nodules.

\section{Soil quality parameters}

Under soil quality parameters, microbial population and microbial activity were recorded for the crop season.

\section{Viable population count of microorganisms}

Viable population counts of microorganisms are presented as bacteria in Table 3, psolubilizer bacteria in Table 4, rhizobium in Table 5 and fungi in Table 6 for different treatments for both years. Generally, there was 
no significant difference recorded for counts of bacterial population under different irrigation treatments in both the years. Significant difference was observed only at harvesting stage in the year 2016-17. However, maximum values were generally recorded under drip irrigation treatments and minimum values were observed under rainfed treatment. Bacterial population increased from initial stage to flowering stage, when the crop was fully established, and then decreased at harvesting stage. Minimum values were recorded at the time of harvesting. Higher values were recorded in the second year (2017-18) as compared to the first year.

P- solubilizer bacteria was seen nonsignificant at harvesting stage in both the seasons but significant difference was recorded at flowering stage. Count was found significantly more in drip irrigation and furrow irrigation treatments and minimum values were recorded in rainfed treatment. With regards to variation from initial stage to flowering stage to harvesting stage the trend was similar to that of overall bacterial count and also higher values were recorded in the second year (2017-18) as compared to the first year.

There was generally non-significant difference in rhizobium count among the different treatments except in the case of flowering stage in the year 2017-18 where rhizobium population was significantly lower under rainfed condition as compared to irrigation treatments. With regards to variation from initial stage to flowering stage to harvesting stage the trend was similar to that of overall bacterial count and also higher values were recorded in the second year (2017-18) as compared to the first year.

There was significant difference in fungi count at flowering stage and non significant at harvesting stage in both the years. At flowering stage, significantly higher values were observed under drip irrigation along the driplines and on ridges in furrow irrigation whereas, significantly low values were observed in drip irrigation rows without drip line, flood irrigation, in furrows of furrow irrigation and rainfed treatment. With regards to variation from initial stage to flowering stage to harvesting stage the trend was similar to that of overall bacterial count and also higher values were recorded in the second year (2017-18) as compared to the first year.

Taking all microbial population observed that is, total bacterial count, $\mathrm{p}$ - solubilizer bacteria, rhizobium and fungi, it can be concluded that in case of total bacterial count and rhizobia, there is insignificant difference between treatments whereas in case of $\mathrm{p}$ - solubilizer bacteria and fungi significant difference between treatments was generally observed at flowering stage.

Significantly higher values were observed for samples taken along driplines and from ridges of furrow irrigation whereas, low values were observed from non dripline rows, flood irrigation, from furrows of furrow irrigation and least values were observed under rainfed treatment. Higher values may be attributed to better soil moisture regime whereas low values may be attributed to either dry or over wet soil condition. Higher values in second year may be due to improved soil conditions due to previously grown legume crops and favourable weather conditions as two good rains were received in initial crop growth period in 2017-18.

\section{(b) Dehydrogenase activity of soil}

Dehydrogenase activity of soil at flowering sage for different treatments is presented in Table 7 for both years. It was observed that activity of dehydrogenase enzyme was found significantly different among irrigation 
treatments in both the years.

Maximum values were observed under drip irrigation from dripline samples and least values were observed under rainfed condition. Significantly higher values were observed under drip irrigation from dripline samples as compared to non dripline samples.

Values of samples from ridges of furrow irrigation were generally non significantly different from that of non dripline samples of drip irrigation treatments. Significantly lower values were observed in rainfed condition, flood irrigation and samples from furrows of furrow irrigation.

Soil dehydrogenase activity is an important indicator of biological activity of microbial population in soil and is also indicative of total microbial population. Dehydrogenase are one of the most important enzymes of the soil ecosystem as they occur intercellular in all living microbial cells and play a significant role in the biological oxidation of soil organic matter. Thus higher dehydrogenase activity may be correlated to better crop growth under drip irrigation treatment.

\section{Yield parameters}

Various yield parameters for chickpea crop are presented in Table 8 for both the years. There was non-significant difference in number of pods per plant. However, number of pods per plant was maximum under drip irrigation treatment. Variation in the number of grains per pod is non-significant among various irrigation treatments however significantly less number of grains were recorded under T5 irrigation treatment as compared to drip irrigation treatments. In first year, there was significant difference in weight of 100 grains between treatments, with generally higher values being recorded under drip irrigation treatments. It may be inferred that grain development was better under drip irrigation system which provides a more conducive soil moisture regime than other irrigation methods.

Maximum yields were recorded under T1 drip irrigation treatment. There were significantly higher yields under both drip irrigation treatments as compared to flood and furrow irrigation treatments. Least yields were recorded under rainfed conditions.

Table.1 Plant growth parameters

\begin{tabular}{|c|c|c|c|c|c|c|c|c|c|c|}
\hline \multirow[t]{2}{*}{ Treatment } & \multicolumn{2}{|c|}{ Plant height $(\mathrm{cm})$} & \multicolumn{2}{|c|}{$\begin{array}{l}\text { Dry weight } \\
\text { of root }(\mathrm{g})\end{array}$} & \multicolumn{2}{|c|}{$\begin{array}{l}\text { Dry weight } \\
\text { of shoot }(g)\end{array}$} & \multicolumn{2}{|c|}{$\begin{array}{l}\text { Leaf area } \\
\text { index }\end{array}$} & \multicolumn{2}{|c|}{$\begin{array}{l}\text { Chlorophyll } \\
\text { content (mg/g) }\end{array}$} \\
\hline & 2016-17 & 2017-18 & $\begin{array}{l}2016- \\
17\end{array}$ & $\begin{array}{l}2017- \\
18\end{array}$ & $\begin{array}{l}2016- \\
17\end{array}$ & $\begin{array}{l}2017- \\
18\end{array}$ & $\begin{array}{l}2016- \\
17\end{array}$ & $\begin{array}{l}2017- \\
18\end{array}$ & $\begin{array}{l}2016- \\
17\end{array}$ & 2017-18 \\
\hline $\mathrm{T} 1$ & 46.22 & 54.77 & 0.37 & 0.50 & 6.87 & 6.95 & 2.40 & 2.67 & 1.3 & 1.25 \\
\hline $\mathrm{T} 2$ & 46.05 & 53.55 & 0.34 & 0.47 & 6.71 & 7.73 & 2.57 & 2.53 & 1.41 & 1.43 \\
\hline T3 & 45.29 & 51.75 & 0.39 & 0.61 & 7.12 & 8.65 & 1.83 & 2.10 & 1.17 & 1.17 \\
\hline $\mathrm{T} 4$ & 42.77 & 50.75 & 0.48 & 0.63 & 7.75 & 8.17 & 1.93 & 2.20 & 1.33 & 1.1 \\
\hline T5 & 40.16 & 45.89 & 0.31 & 0.38 & 3.17 & 4.63 & 1.23 & 1.63 & 1.13 & 1.15 \\
\hline $\mathrm{CD}(\mathrm{p}=0.05)$ & 1.09 & 2.98 & NS & NS & 1.65 & 2.12 & 0.51 & 0.44 & 0.18 & NS \\
\hline
\end{tabular}


Table.2 Symbiotic traits

\begin{tabular}{|l|c|c|c|c|c|c|}
\hline Treatment & \multicolumn{2}{|c|}{ Number of nodules per plant } & \multicolumn{2}{|c|}{$\begin{array}{c}\text { Dry weight of } \\
\text { nodules per plant (g) }\end{array}$} & \multicolumn{2}{c|}{$\begin{array}{c}\text { Leghaemoglobin } \\
\text { content }(\mathrm{mg} / \mathrm{g})\end{array}$} \\
\cline { 2 - 7 } & $\mathbf{2 0 1 6 - 1 7}$ & $\mathbf{2 0 1 7 - 1 8}$ & $\mathbf{2 0 1 6 - 1 7}$ & $\mathbf{2 0 1 7 - 1 8}$ & $\mathbf{2 0 1 6 - 1 7}$ & $\mathbf{2 0 1 7 - 1 8}$ \\
\hline T1 & 63.67 & 69 & 0.120 & 0.153 & 3.51 & 3.68 \\
\hline T2 & 52.67 & 65 & 0.118 & 0.144 & 3.45 & 3.65 \\
\hline T3 & 65.67 & 64.67 & 0.099 & 0.127 & 3.14 & 3.39 \\
\hline T4 & 65 & 61 & 0.114 & 0.148 & 3.18 & 3.23 \\
\hline T5 & 38.33 & 41.33 & 0.0433 & 0.077 & 2.93 & 3.03 \\
\hline CD $(\mathrm{p}=0.05)$ & $\mathbf{1 6 . 2 4}$ & NS & $\mathbf{0 . 0 3 7}$ & $\mathbf{0 . 0 3 2}$ & $\mathbf{0 . 2 7}$ & $\mathbf{0 . 3 5}$ \\
\hline
\end{tabular}

Table.3 Viable population count of bacteria

\begin{tabular}{|l|l|l|l|l|l|l|}
\hline \multirow{2}{*}{ Treatment } & \multicolumn{9}{l}{ Viable Population Density (log Cfu/g of soil) } & \multicolumn{2}{l|}{} \\
\cline { 2 - 7 } & Initial stage & \multicolumn{2}{l|}{ Flowering stage } & \multicolumn{2}{l|}{ Harvesting stage } \\
\cline { 2 - 6 } & $\mathbf{2 0 1 6 - 1 7}$ & $\mathbf{2 0 1 7 - 1 8}$ & $\mathbf{2 0 1 6 - 1 7}$ & $\mathbf{2 0 1 7 - 1 8}$ & $\mathbf{2 0 1 6 - 1 7}$ & $\mathbf{2 0 1 7 - 1 8}$ \\
\hline T1 RWDL & 7.84 & 8.02 & 8.63 & 8.92 & 7.11 & 7.53 \\
\hline T1 RWoDL & & & 8.49 & 8.89 & 7.05 & 7.43 \\
\hline T2 RIDGE & & & 8.62 & 8.94 & 7.30 & 7.53 \\
\hline T2 FURROW & & & 8.50 & 8.86 & 6.84 & 7.47 \\
\hline T3 & & 8.49 & 8.77 & 7.58 & 7.39 \\
\hline T4 RIDGE & & 8.46 & 8.87 & 6.93 & 7.45 \\
\hline T4 FURROW & & 8.36 & 8.78 & 6.70 & 7.43 \\
\hline T5 & & 8.24 & 8.62 & 7.04 & 7.35 \\
\hline CD $(\mathrm{p}=0.05)$ & & & NS & NS & $\mathbf{0 . 1 6}$ & NS \\
\hline
\end{tabular}

Table.4 Viable population count of p- solubilizer (pseudomonas) bacteria

\begin{tabular}{|l|l|l|l|l|c|c|}
\hline \multirow{2}{*}{ Treatment } & \multicolumn{9}{|l}{ Viable Population Density (log Cfu/g of soil) } & \multicolumn{2}{l|}{} \\
\cline { 2 - 7 } & Initial stage & \multicolumn{3}{|c|}{ Flowering stage } & \multicolumn{2}{l|}{ Harvesting stage } \\
\cline { 2 - 7 } & $\mathbf{2 0 1 6 - 1 7}$ & $\mathbf{2 0 1 7 - 1 8}$ & $\mathbf{2 0 1 6 - 1 7}$ & $\mathbf{2 0 1 7 - 1 8}$ & $\mathbf{2 0 1 6 - 1 7}$ & $\mathbf{2 0 1 7 - 1 8}$ \\
\hline T1 RWDL & 6.80 & 7.02 & 7.50 & 7.81 & 7.24 & 7.41 \\
\hline T1 RWoDL & & & 7.37 & 7.58 & 7.22 & 7.38 \\
\hline T2 RIDGE & & & 7.74 & 7.82 & 7.25 & 7.42 \\
\hline T2 FURROW & & & 7.64 & 7.66 & 7.21 & 7.37 \\
\hline T3 & & 7.43 & 7.64 & 7.20 & 7.29 \\
\hline T4 RIDGE & & & 7.47 & 7.53 & 7.23 & 7.37 \\
\hline T4 FURROW & & & 7.21 & 7.45 & 7.21 & 7.39 \\
\hline T5 & & 7.20 & 7.39 & 7.19 & 7.41 \\
\hline CD $(\mathrm{p}=0.05)$ & & & $\mathbf{0 . 2 0}$ & $\mathbf{0 . 1 6}$ & $\mathbf{N S}$ & NS \\
\hline
\end{tabular}


Table.5 Viable population count of rhizobium

\begin{tabular}{|c|c|c|c|c|c|c|}
\hline \multirow[t]{3}{*}{ Treatment } & \multicolumn{6}{|c|}{ Viable Population Density (log Cfu/g of soil) } \\
\hline & \multicolumn{2}{|c|}{ Initial stage } & \multicolumn{2}{|c|}{ Flowering stage } & \multicolumn{2}{|c|}{ Harvesting stage } \\
\hline & 2016-17 & 2017-18 & 2016-17 & 2017-18 & 2016-17 & 2017-18 \\
\hline T1 RWDL & \multirow[t]{8}{*}{4.90} & \multirow[t]{8}{*}{5.05} & 5.61 & 5.63 & 5.29 & 5.31 \\
\hline T1 RWoDL & & & 5.53 & 5.64 & 5.18 & 5.21 \\
\hline T2 RIDGE & & & 5.69 & 5.69 & 5.28 & 5.28 \\
\hline T2 FURROW & & & 5.48 & 5.45 & 5.13 & 5.18 \\
\hline $\mathrm{T} 3$ & & & 5.50 & 5.51 & 5.23 & 5.28 \\
\hline T4 RIDGE & & & 5.58 & 5.58 & 5.23 & 5.28 \\
\hline T4 FURROW & & & 5.50 & 5.53 & 5.10 & 5.18 \\
\hline T5 & & & 5.45 & 5.43 & 5.10 & 5.15 \\
\hline$C D(p=0.05)$ & & & NS & 0.14 & NS & NS \\
\hline
\end{tabular}

Table.6 Viable population count of fungi

\begin{tabular}{|c|c|c|c|c|c|c|}
\hline \multirow[t]{3}{*}{ Treatment } & \multicolumn{6}{|c|}{ Viable Population Density ( $\log \mathrm{Cfu} / \mathrm{g}$ of soil) } \\
\hline & \multicolumn{2}{|c|}{ Initial stage } & \multicolumn{2}{|c|}{ Flowering stage } & \multicolumn{2}{|c|}{ Harvesting stage } \\
\hline & 2016-17 & 2017-18 & 2016-17 & 2017-18 & 2016-17 & 2017-18 \\
\hline T1 RWDL & \multirow[t]{8}{*}{4.15} & \multirow[t]{8}{*}{4.30} & 4.31 & 4.46 & 4.10 & 4.23 \\
\hline T1 RWoDL & & & 4.28 & 4.28 & 4.05 & 4.20 \\
\hline T2 RIDGE & & & 4.33 & 4.41 & 4.20 & 4.23 \\
\hline T2 FURROW & & & 4.15 & 4.10 & 4.15 & 4.18 \\
\hline T3 & & & 4.15 & 4.18 & 4.15 & 4.10 \\
\hline T4 RIDGE & & & 4.16 & 4.23 & 4.18 & 4.18 \\
\hline T4 FURROW & & & 4.10 & 4.16 & 4.10 & 4.10 \\
\hline T5 & & & 4.05 & 4.15 & 4.00 & 4.05 \\
\hline $\mathrm{CD}(\mathrm{p}=0.05)$ & & & 0.15 & 0.13 & NS & NS \\
\hline
\end{tabular}

Table.7 Dehydrogenase activity of soil in chickpea

\begin{tabular}{|l|c|c|}
\hline \multirow{2}{*}{ Treatment } & Dehydrogenase activity $\left(\mu \mathrm{TPF}^{-1}\right.$ soil $^{-1)}$ \\
\cline { 2 - 3 } & $\mathbf{2 0 1 6 - 1 7}$ & $\mathbf{2 0 1 7 - 1 8}$ \\
\hline T1 RWDL & 16.1 & 16.51 \\
\hline T1 RWoDL & 15.46 & 16.36 \\
\hline T2 RIDGE & 16.14 & 16.92 \\
\hline T2 FURROW & 15.1 & 15.57 \\
\hline T3 & 13.37 & 14.83 \\
\hline T4 RIDGE & 14.39 & 15.04 \\
\hline T4 FURROW & 13.14 & 13.61 \\
\hline T5 & 11.99 & 13.09 \\
\hline CD $(\mathrm{p}=0.05)$ & $\mathbf{0 . 8 8}$ & $\mathbf{0 . 9 8}$ \\
\hline
\end{tabular}


Table.8 Yield parameters

\begin{tabular}{|l|c|c|c|c|c|c|c|c|}
\hline \multirow{2}{*}{ Treatment } & \multicolumn{2}{|c|}{$\begin{array}{c}\text { Number of pods } \\
\text { per plant }\end{array}$} & \multicolumn{2}{|c|}{$\begin{array}{c}\text { Number of grains } \\
\text { per pod }\end{array}$} & \multicolumn{2}{|c|}{$\begin{array}{c}\text { Weight of } 100 \\
\text { grains }(\mathrm{g})\end{array}$} & \multicolumn{2}{c|}{ Yield (Kg/ha) } \\
\cline { 2 - 10 } & $\mathbf{2 0 1 6 - 1 7}$ & $\mathbf{2 0 1 7 - 1 8}$ & $\mathbf{2 0 1 6 - 1 7}$ & $\mathbf{2 0 1 7 -}$ & $\mathbf{2 0 1 6 -}$ & $\mathbf{2 0 1 7 - 1 8}$ & $\mathbf{2 0 1 6 -}$ & $\mathbf{2 0 1 7 - 1 8}$ \\
& & & & $\mathbf{1 8}$ & $\mathbf{1 7}$ & & $\mathbf{1 7}$ & \\
\hline T1 & 30.47 & 32.47 & 1.52 & 1.31 & 17.87 & 19.84 & 1970.62 & 2135.8 \\
\hline T2 & 32.87 & 33.27 & 1.44 & 1.41 & 16.57 & 18.79 & 1878.62 & 2013.9 \\
\hline T3 & 22.47 & 26.27 & 1.52 & 1.40 & 16.37 & 17.82 & 1422.14 & 1643.17 \\
\hline T4 & 28.33 & 31.30 & 1.46 & 1.36 & 16.69 & 18.68 & 1657.38 & 1825.2 \\
\hline T5 & 16.00 & 24.00 & 1.33 & 1.30 & 14.14 & 17.68 & 1066.78 & 1363.8 \\
\hline CD $(p=0.05)$ & NS & NS & NS & NS & $\mathbf{1 . 3 3}$ & NS & $\mathbf{2 1 9 . 7 5}$ & $\mathbf{1 5 0 . 5 3}$ \\
\hline
\end{tabular}

There was an improvement of $10 \%$ in yield under irrigation treatments in second year while a marked improvement of $27 \%$ was recorded in rainfed condition in second year which may be attributed to improved soil moisture condition due to rainfall in the initial growth period of the crop in 2017-18.

Hence it may be concluded that drip irrigation treatments positively impacts the health of nodules and microbial activity in soil, which leads to better growth parameters and yields of chickpea crop.

Higher yields under drip irrigation system may be attributed to better plant growth (as reflected in plant height and leaf area index) and better grain development due to better soil moisture regime due to frequent irrigation. Though difference in total microbial population and nodule formation was insignificant among the various irrigation treatments, there was a significant difference in microbial activity and health of the nodules under drip irrigation as reflected in dehydrogenase activity of soil and leghaemoglobin content of nodules respectively Also as reported the dry weight of nodules was maximum under drip irrigation treatments even though number of nodules per plant was more or less same under different irrigation treatments, indicating a better average size of nodules under drip irrigation. The overall size and health of nodules formation under drip irrigation may have also contributed to higher yields.

\section{References}

Anonymous (2016) Package of practices for rabi crops. Pp 29-36. Punjab Agricultural University, Ludhiana.

FAOSTAT (2018) retrieved from http://www.fao.org/faostat/en/\#data/Q $\mathrm{C}$ on $22 / 05 / 2018$.

Phene CJ and Howell TA (1984) Soil sensor control of high frequency irrigation. Trans. ASAE 27: 392-396.

Singh Harpinder (2016) Impact of different irrigation methods on microbial activity in summer mungbean. $\mathrm{M}$. Tech. thesis, Punjab Agricultural University, Ludhiana

Tabatabai MA (1982) Soil enzymes. In methods of analysis, part $2,2^{\text {nd }}$ Ed. A L page et al (eds). Agro 9: 903-47.

Wilson DO and Reisenauer (1963) Determination of leghaemoglobin in legume nodules. Analy Biochem 6: 2730.

Zahran HH (1999) Rhizobium-legume symbiosis and nitrogen fixation under severe conditions and in an arid climate. Microbiol Mol Biol $R$ 63: 968-89. 
How to cite this article:

Neha Singhal, Poonam Sharma, Mukesh Siag, Rakesh Sharda and Nikhil Gladwin Cutting. 2018. Impact of Different Irrigation Methods on Microbial Activity in Chickpea Crop. Int.J.Curr.Microbiol.App.Sci. 7(07): 1921-1930. doi: https://doi.org/10.20546/ijcmas.2018.707.227 